\title{
Factors Affecting Consumers' Decisions in Using BNI Credit Cards in Makassar
}

\author{
Sapinah \\ Sekolah Tinggi Keguruan dan Ilmu Pendidikan \\ Makassar, South Sulawesi, Indonesia
}

\author{
Andi Annisa Sulolipu \\ Sekolah Tinggi Keguruan dan Ilmu Pendidikan \\ Makassar, South Sulawesi, Indonesia \\ annisafachri.aas@gmail.com
}

\begin{abstract}
The study aimed to find out the simultaneous influence on product, price, place and promotion to the consumers' decision by using BNI Makassar credit cards. The population of this research was 250 consumers and the samples were 180 consumers. The data were collected by using questionnaire, observation and documentation. The data analyses were multiple linear regression analysis. This result indicates that: 1) the product variable (X1) had positive influence but there was not a significant influence in the consumers' decision on using BNI credit cards (Y). 2) The price variable (X2) had positive influence but there was not a significant influence in the consumers' decision on using BNI credit card (Y). 3) The place variable (X3) had positive and there was a significant influence in the consumers' decision on using BNI credit cards (Y). 4) The Promotion variable (X4) had positive influence but there was not a significant influence in the consumers' decision on using BNI credit card (Y). 5) The variables of the marketing mix (product, price, place and promotion) influenced in the consumers' decisions on using BNI credit card simultaneously, positively and significantly.
\end{abstract}

Keywords: credit cards, product, price, place, promotion

\section{INTRODUCTION}

Life in the big cities are making people tend to want something that is fast-paced, easy and practical, including for activities that are consumptive. This phenomenon is responded by the bank by issuing credit cards as a tool to offer practicality and safety in shopping. the existence of credit cards for some people is very closely related to the lifestyle of credit card owners.

Bank as a financial institution has main activities collect funds from the people and distribute the funds to the public as well as give other banking service [1], one of them is giving credit card as replacement of cash [2] that has function and use not only as a payment, but also as a safe and practical business transaction [3]. According to Brito and Hartley, the number of credit card users increased 15\% (16 million people to 16,5 million people) [4].

Financial decision-making by individuals is influenced by many factors that are less well known in the financial models of the company, namely psychological and social factors. One of them is the mental accounting aspect. Mental accounting is a series of cognitive operations used by individuals or households in coding, category making, and evaluating their financial activities. Mental accounting focuses on how one should respond to and evaluate a situation when there are two or more possible outcomes, in particular how to combine the possibilities of the outcome. Mental accounting refers to the tendency of people to separate their money into separate accounts based on various subjective criteria, such as the source of money and goals for each account.

One of the most influential aspects of marketing in attracting funds from the public and channeling funds to the public is the services provided to customers. These services can be (1) physical form and can be seen and felt by customers such as the appearance of bank buildings, facilities owned and provided to customers, communication equipment used by banks and other physical forms; (2) reliability or reliability in providing services to customers; (3) responsiveness and empathy or speed level in responding to customers and special attention given by the bank to customers. Matzler \& Hinterhuber and Bazan argue that successful banks provide excellent satisfaction to customers and can reach 40 percent more likely to be loyal customers rather than just satisfied customers [5], [6].

The growth rate of the credit card business that significantly increases from year to year can show that people's purchasing power is also increasing. It becomes a positive indicator for credit card business will credit card growth will be more prospective in the future. Recorded almost all largescale banks in the country have plunged in the credit card business and one of them is Bank BNI.

Perceiving this phenomenon indirectly, the banking sector has to be ready to face and creates good and qualified offers to make consumers satisfied and interested in it because the banking survival is affected by the customers. Therefore, customer service needs to be improved [7]. Moreover, one of bank that improves its service is BNI, founded in October 1997 and established a new division which is called a division of credit card business management or BNI Card Center, which has branches in several cities in Indonesia including Makassar. The development of credit card use is increasing every time so it is necessary to determine factors that influence the consumers' decision uses BNI credit cards. 


\section{RESEARCH METHODS}

This research was a quantitative research conducted at BNI Bank of Makassar, on JL. AP. Pettarani New Zamrud Building Blok D No. 15 Makassar. The population of this study was 250 people with samples of 180 people chosen by using random sampling method with proportionate stratified random sampling technique. The data were collected by using questionnaire, observation, and documentation.

The data analysis technique used to answer the problem and hypothesis which was proposed in this research was Multiple Linear Regression Analysis.

This analysis was intended to predict the condition of dependent variable (Y) when two or more independent variables $(\mathrm{X})$ as predicator factors manipulated [8]. This analysis was used to determine the significant influence of product, price, place and promotion in the consumers' decision on using BNI credit cards.

$\begin{array}{ll}\mathrm{Yi}=\mathrm{a}+\mathrm{b} 1 \mathrm{x} 1+\mathrm{b} 2 \mathrm{X} 2 & +\mathrm{b} 3 \mathrm{X} 3+\mathrm{b} 4 \mathrm{X} 4+\mathrm{e} 1 \\ \text { Information: } & =\text { Consumers' Decision } \\ \mathrm{Y} & =\text { Constant } \\ \mathrm{a} & =\text { Regression coefficient } \\ \mathrm{b} 1, \mathrm{~b} 2, \mathrm{~b} 3, \mathrm{~b} 4 & =\text { Product (Credit Cards) } \\ \mathrm{X} 1 & =\text { Price (Bank interest and lower } \\ \mathrm{X} 2 & \\ & =\text { Pdministrative) } \\ \mathrm{X} 3 & =\text { Promotion (Advertising) } \\ \mathrm{X} 4 & =\text { Error }\end{array}$

\section{RESULT AND DISCUSSION}

\section{A. Result}

In this study, there were four (4) factors that influenced the consumers on using BNI credit cards: product, price, place and promotion. The followings are 180 samples taken from BNI credit card users:

\section{1) R. Square}

Determining the influence of the variables of product, price, place and promotion as independent variables in the consumers' decision. It could be seen from the magnitude of coefficient of determination ( $\mathrm{R}$ Square) which had a positive value of 0.956 or $95.6 \%$, it suggests that $95.6 \%$ of consumer decision variables were influenced by product, price, place and promotion, while the remaining $4.6 \%$ was influenced by other variables which were not examined in this research.

\section{2) T-Test}

The result of the T-test shows that the variable of product (X1) with $1.306 \mathrm{~T}$-value and $0.193>\alpha=0.05$ significance indicates that it did not have significant influence in the consumers' decision on using BNI credit card. The variable of price (X2) with $-0.391 \mathrm{~T}$ Value and 0.696> $\alpha=0.05$ significance shows that it did not have significant influence in the consumers' decision on using BNI credit card. The variable of place (X3) with $5.242 \mathrm{~T}$ - value and $0.000<\alpha=0.05$ significance shows that it had positive and significant influence in consumers' decision on using BNI credit card. Instead, the variable of promotion (X4) with $1.604 \mathrm{~T}$ value and $0.110>\alpha$ 0.05 significance shows that the variable of promotion did not have significant influence in the consumers' decision on using BNI credit card.

\section{3) F-Test}

The result of the F-test shows that $952.237 \mathrm{~F}$ value with $0.000<0.05$ significance indicates that the variables of product, price, place and promotion simultaneously had positive and significant influence in the consumers' decisions on using BNI credit card.

\section{B. Discussion}

\section{1) Product (X1)}

The result of the T-test shows that the product (X1) had positive influence and did not influence in consumers' decision (Y) significantly on using BNI credit card. Thus, the product (X1) offered by BNI did not influence the consumers' decision (Y) on using BNI credit card. It indicates that the product such as credit card that was offered by BNI did not influence the consumers' decision on using credit card. It was due to product offered by BNI less-attractive for the consumers, supported on the statement of Kotler who stated that "the products offered to the market to get attention, purchase and use of the products can satisfy and fulfill customer needs" [9].

The result of Hidayat study proves that theoretical studies and empirical studies that state and prove a positive and significant causal relationship between product quality and customer satisfaction can also be used for study in the field of banking in Indonesia, especially in Bank Mandiri in East Java [10].

\section{2) Price $(X 2)$}

The t-test result shows that the price (X2) had positive effect and did not significantly influence the consumers' decision (Y) on using BNI Makassar credit card, thus the price (X2) which is offered by BNI did not influence the consumers' decision (Y) on using BNI credit card. It indicates that if fees offered by BNI decreased, consumers would make decision to use BNI credit card and if fees offered by BNI increased, the consumers' decision to have BNI credit card would decrease and they would prefer to choose credit card from other banks. Therefore, the price should be adjusted with the consumer ability. According to Puspasari, "the price must be reasonable and in accordance with consumer income" [11]. Hustic and Gregurec also stated that "the price could be the only reason to buy particular products" [12].

The result of Hidayat study proves that theoretical studies and empirical studies that state and prove a positive and significant causal relationship between value of product and customer satisfaction [10]. The value of product related to the price of the produk were more cheap than other Bank.

\section{3) Place (X3)}

The t-test result shows that place (X3) had positive and significant influence in consumers' decision (Y) on using BNI 
credit card. Thus, place (X3) offered by BNI influenced the consumers' decision (Y) on using BNI credit card. It shows that BNI location was the reason why consumers decided to use BNI credit card. DesJardins et al.; Olson and Shi stated that "the location or place would influence the cost of production and the ability of company to compete with one another" [13], [14].

Location affects strategic dimensions, such as flexibility, competitive positioning, demand management, and strategic focus [15]. The flexibility of a location is a measure of the extent to which a service is able to react to a changing economic situation. The decision on site selection relates to long-term commitment to capital intensive aspects, so service providers should consider, select and select locations responsive to future economic, demographic, cultural, competition and regulatory changes. Peter and Donnelly argues that a good location guarantees the availability of fast access, can attract a large number of consumers and is strong enough to change the pattern of shopping and consumer purchases [16]. Companies should carefully consider the selection of business locations for future development [17].

\section{4) Promotion (X4)}

The T-test result shows that the promotion (X4) had positive influence but did not significantly influence consumers' decision (Y) on using BNI Makassar credit card. Thus promotion (X4) offered by BNI did not influence the consumers' decision (Y) on using BNI credit card. It shows that the promotion conducted by BNI did not interfere the consumers' choice on using BNI credit card. The result of Ftest shows that the variables of product, price, place and promotion simultaneously and significantly influenced consumers' decision (Y) on using BNI credit card. It indicates that the product, price, place and promotion activities conducted by BNI could be the reason why the consumers decided on using BNI credit card or not.

Accordance to Tjiptono stated sales promotion is a form of direct persuasion through the use of various incentives that can be regulated to stimulate the purchase of products immediately and / or increase the number of items customers buy [18]. Meanwhile, according to Kotler and Armstrong, sales promotion short-term incentives to encourage the purchase or sale of products or services [17].

\section{CONCLUSION}

Based on data obtained, there were several reasons why the community used BNI credit card. Each consumer had different perspective on his/her intention on using credit card such as the criteria of product, price, place and promotion. Furthermore, to test the dependent variable through F-test indicates that the product, price, place and promotion simultaneously had positive and significant influence in the consumers' decision on using BNI credit card. Whereas, to test the independent variable through $\mathrm{T}$-test indicates that the product, price and promotion partially had positive influence but did not significantly influence in the consumers' decision on using BNI credit card. On the other hand, the variable of place had positive and significant influence in consumers' decision on using credit card.

\section{REFERENCES}

[1] B. White, L. Braentner, and E. Towery, Financial Statement Analysis. New York: Wiley, 1993.

[2] R. H. McLeod, 'Indonesia's new banking law', Bull. Indones. Econ. Stud., vol. 28, no. 3, pp. 107-122, 1992.

[3] H. Wijayanto and U. Sumarwan, 'Analysis of the Factors Influencing Bogor Senior High School Student Choice in Choosing Bogor Agricultural University (Indonesia) For Further Study', J. Educ. $e$ Learning Res., vol. 3, no. 3, pp. 87-97, 2016.

[4] D. L. Brito and P. R. Hartley, 'Consumer rationality and credit cards', $J$. Polit. Econ., vol. 103, no. 2, pp. 400-433, 1995.

[5] K. Matzler and H. H. Hinterhuber, 'How to make product development projects more successful by integrating Kano's model of customer satisfaction into quality function deployment', Technovation, vol. 18, no. 1, pp. 25-38, 1998.

[6] S. Bazan, 'Customer service and satisfaction: competitive advantage and beyond', New Engl. J. Entrep., vol. 1, no. 1, p. 23, 1998.

[7] C. Mwangi, 'Factors that influence Consumer Satisfaction with credit cards: a case of the NIC bank limited.' United States International University-Africa, 2014.

[8] P. R. Hinton, I. McMurray, and C. Brownlow, SPSS explained. Routledge, 2014.

[9] P. Kotler, 'Marketing Management, millenium edition: Custom Edition for University of Phoenix'. Pearson Custom, 2012.

[10] R. Hidayat, 'Pengaruh kualitas layanan, kualitas produk dan nilai nasabah terhadap kepuasan dan loyalitas nasabah Bank Mandiri', $J$. Manaj. dan kewirausahaan, vol. 11, no. 1, p. pp-59, 2009.

[11] R. Puspasari, 'The Influence of Promotion Cost and Distribution Cost Towards The Sales of Oriflame Products in Pekanbaru', 2013.

[12] I. Hustic and I. Gregurec, 'The influence of price on customer's purchase decision', in Central European Conference on Information and Intelligent Systems, 2015, p. 27.

[13] D. L. Olson and Y. Shi, Introduction to business data mining, vol. 10. McGraw-Hill/Irwin Englewood Cliffs, 2007.

[14] J. R. DesJardins et al., An introduction to business ethics. McGraw-Hill New York, 2003.

[15] J. A. Fitzsimmons and M. J. Fitzsimmons, Service management for competitive advantage. McGraw-Hill New York, NY, 1994.

[16] J. P. Peter and J. H. Donnelly, A preface to marketing management. McGraw-Hill/Irwin, 2000.

[17] P. Kotler and G. Armstrong, Principles of marketing. Pearson education, 2010.

[18] T. Fandy, 'Strategi Pemasaran, Edisi III, CV', ANDI OFFSET, ANDI Yogyakarta, 2008. 